\title{
CARDIM DE CARVALHO AND THE POST KEYNESIANS ON FISCAL POLICY: THE ECONOMIC CONSEQUENCES OF AUSTERITY
}

\begin{abstract}
Gilberto Libanio $^{a}$

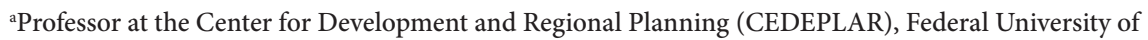
Minas Gerais (UFMG). Belo Horizonte, MG, Brazil. ORCID: https://orcid.org/0000-0002-4583-4346.
\end{abstract}

\begin{abstract}
This paper discusses the role of austerity policies in the long-run path of the economy, from a Post Keynesian perspective. Our starting points are the role of aggregate demand to determine output in the short and long run and the importance of fiscal policy as a tool for demand stabilization. As main theoretical elements, the paper uses the concept of corridor of stability, adapted by Cardim de Carvalho (2016), and Keynes's model of shifting equilibrium, as presented by Kregel (1976). We argue that adverse output shocks, followed by contractionary policies that prolong the recession, have an impact on the propensity to consume, liquidity preference, and the marginal efficiency of capital, and thus define a new growth trend for the economy. Not only the depth but also the length of the recession matters if the system is to absorb shocks and return to its previous growth trend. As a result of long recessions, a new trend may arise and be acknowledged as "normal", thus defining a new corridor of stability.
\end{abstract}

KEYWORDS: fiscal policy; austerity; unemployment equilibrium.

JEL CODES: E32; E62. 


\section{CARDIM DE CARVALHO E OS PÓS-KEYNESIANOS SOBRE POLÍTICA FISCAL: AS CONSEQUÊNCIAS ECONÔMICAS DA AUSTERIDADE}

RESUMO: Este artigo procura discutir os efeitos de políticas de austeridade fiscal sobre a trajetória da economia no longo prazo a partir de uma perspectiva póskeynesiana. Toma como pontos de partida o papel da demanda agregada na determinação do produto no curto e longo prazo e a importância da política fiscal como instrumento de estabilização do produto. $\mathrm{O}$ artigo utiliza como elementos teóricos o conceito de corredor de estabilidade adaptado por Cardim de Carvalho (2016) e o modelo de equilíbrio móvel de Keynes, tal como apresentado por Kregel (1976). Argumenta-se que choques adversos sobre o produto, seguidos de políticas restritivas que prolongam a recessão, impactam a propensão a consumir, a preferência pela liquidez e a eficiência marginal do capital, gerando uma nova trajetória de longo prazo para a economia. Não apenas a profundidade da crise, mas também sua duração importa para a possibilidade de o sistema absorver os choques e retornar à sua trajetória anterior de crescimento. Recessões longas levam a uma nova trajetória reconhecida como "normal", em torno da qual um novo corredor de estabilidade se estabelece.

PALAVRAS-CHAVE: Política fiscal; austeridade; equilíbrio com desemprego. 


\section{INTRODUCTION}

Economic policies have always been a crucial issue for Keynes, Post Keynesians in general, and Fernando Cardim de Carvalho in particular. Such an interest is sparked by the recognition of systemic flaws in capitalist economies, which Keynes (1936) acknowledged as the system's inability to promote full employment of labor and its tendency to generate income inequality. The former, in particular, received a great deal of attention in Keynes's 'General Theory', where he attempted to develop a theoretical model to explain how difficult it is to create the effective demand needed for the economy to achieve full utilization of resources - labor and capital.

As it is well known, Keynes wrote his General Theory amidst the great depression of the 1930s - a period of persistent unemployment, falling wages and prices, and insufficient aggregate demand. The aftermath of the 2008 financial crisis and that of the 1930s depression compare to one another in many aspects. Then and now, after a sharp fall in the level of economic activity, a stagnant economy and depressed expectations of firms and households sparked high and persistent unemployment rates.

Interestingly, both in the 1930s and in the 2010s, austerity policies surged as the appropriate response of governments to resume economic growth. In one of his last papers, Cardim de Carvalho (2018) examined how the defense of austerity policies by the Treasury View in the 1920s compared to that of the German Ministry of Finance in the 2010s. Carvalho's noteworthy argument is that austerity and fiscal discipline are not equivalent. In particular, "fiscal austerity is the effort to balance the budget and reduce public debt under recessionary or depression conditions" (CARVALHO, 2018, p. 264, emphasis in original).

The rationale behind austerity is that fiscal contractions could be expansionary. The assumption that a decline in government expenditures comes along with higher private spending - following a type of reverse crowding-out effect - gives theoretical ground to the defense of austerity policies. The reason is that a tight fiscal policy is supposed to bring about expectations of lower taxes and/or lower interest rates, which tend to increase confidence in the financial markets and, thus, encourage consumption, investment, and net exports.

However, the idea of expansionary fiscal contractions does not find consistent empirical support. As King et al. (2012, p. 6) put it: “[i]n reality, the historical record provides very little evidence that austerity measures will be effective, particularly in a context of recession."

Giavazzi and Pagano (1990) deliver an early empirical assessment of the effects of fiscal consolidations. They examine the case of two small European countries that managed to reverse budget deficits in the 1980s: Denmark and Ireland. Regarding 
Denmark, Giavazzi and Pagano argue that cuts in government spending are behind increases in private consumption. However, such expansionary effect may also relate to concomitant monetary disinflation based on fixed exchange rates and capital account liberalization, which lead to a sharp fall in nominal and real interest rates. For Ireland, in turn, their main finding is that disposable income primarily guides consumption (arguably due to liquidity constraints), being expansionary fiscal contraction not directly confirmed.

Perotti (2011) expands upon Giavazzi and Pagano's investigation and presents case studies of four multi-year fiscal consolidations: Denmark and Ireland in the 1980s, and Finland and Sweden in the 1990s. His study focuses on the short-run effects of budget consolidations, particularly those mostly based on public spending cuts. Evidence shows that output expansions followed fiscal consolidation, but GDP growth did not rely on the so-called 'confidence' channel, as described before. Instead, the increasing private spending was mostly associated with a sharp decline in nominal interest rates, and increasing exports were behind competitive gains due to wage moderation and exchange rate devaluations.

Alesina et al. (2017) analyze the effects of fiscal consolidation on output for 16 OECD countries from 1978 to 2014. The authors divide fiscal variables into three components: taxes, government transfer, and public spending. Results suggest that tax-based budget adjustments "cause deep and long lasting recession" (ALESINA et al., 2017, p. 2), and fiscal consolidations mainly related to spending cuts do not cause any significant negative effects on output. The main explanation for these results is that if cuts in public spending is permanent higher disposable income will follow, raising private consumption and partially compensating for the decrease in government spending.

Blyth (2013) provides a historical account of arguments in favor of austerity policies and examines the effects of fiscal consolidations. He argues that episodes of GDP expansions following budget cuts do not relate to expectations or confidence. Instead, results show how devaluation and wage moderation can boost the economy when its trade partners are growing, and that boost, in turn, allows for fiscal consolidation.

Botta and Tori (2018) also provide empirical evidence on the subject by analyzing a sample of 28 developed countries between 2007 and 2016. Their results suggest that fiscal consolidations could have affected economic activity through channels that might not have been operative or have operated in the opposite direction to what austerity supporters expected. Thus, their main conclusion is that "EAT [expansionary austerity theory] policy prescriptions should be taken as purely theoretical speculations that rely on unrealistic assumptions and lack strong empirical grounds" (BOTTA and TORI, 2018, p. 395). 
The failure of austerity policies to promote economic recovery comes as no surprise if one analyzes the economy from a Keynesian perspective. The starting point is the understanding that - as Keynes pointed out - macroeconomic relations differ from those observed at the micro-level. The reason is that taking the principle of effective demand into account, aggregate expenditures determine aggregate income, and thus an increase in savings at the macro-level reduces output instead of expanding it. As Steindl (1985, p. 99) puts it: "for the individual household saving (...) leads to an accumulation of assets. For society as a whole when people spend less they reduce each other's income and the wealth of society is reduced." Therefore, as Keynes pointed out, the analogy between the individual household and society as a whole is misleading, which pre-Keynesian economics and current proponents of austerity policies broadly use.

More specifically, regarding fiscal policies, Cardim de Carvalho (2018) argues that the idea that governments face the same financial constraints as a household is a fallacy of composition.

The fallacy is to miss the fact that while a family's expenditures are unlikely to affect their own income, the opposite happens with government expenditures. By spending, the government is able to increase aggregate income and, thus, tax revenues. (CARVALHO, 2018, p. 282, n. 49)

This paper aims to explore the economic consequences of austerity policies from a Post Keynesian perspective. To that purpose, two main theoretical elements ground the analysis. The first one is Keynes's shifting equilibrium model, as Kregel (1976) summarized it, to deal with the role of expectations in determining underemployment equilibrium. The second one is Carvalho's (2016) concept of "corridor of stability" to discuss why austerity policies by prolonging stagnation may lead to permanent changes in income and employment. Thus, the main contribution of this paper relies on using Keynes' and Post Keynesians' theoretical tools to explore the channels through which short-run contractionary fiscal policies may lead to negative long-run effects.

The remainder of the paper is organized as follows. The next section briefly presents some Post Keynesian views on fiscal policy, following the works of Keynes and Cardim de Carvalho, among others. It stresses the importance of government expenses to stabilize aggregate demand under uncertainty and outline proposals for fiscal policy. Section two adapts Carvalho's (2016) concept of 'corridor of stability' and Keynes's shifting equilibrium model, as Kregel (1976) described it, to discuss the impact of austerity policies in the short and long-run. Section three summarizes the discussion and concludes the paper. 


\section{FISCAL POLICY AND AGGREGATE DEMAND}

The starting point for discussing fiscal policy from a Keynesian perspective is to acknowledge that the economy can reach equilibrium below full employment due to insufficient effective demand and that it will not achieve full utilization of resources automatically. As Keynes argued about the 1930s' depression: “[ $t]$ he system is not selfadjusting and, without purposive direction, it is incapable of translating our actual poverty into our potential plenty" (KEYNES, 1973, p. 491).

Moreover, one acknowledges that governments possess key tools to influence the economy, which is beyond what private agents do. States can mobilize resources, build institutions, change laws and policies, accumulate debt, and above all they are more capable of guiding market expectations than any other agent.

An important feature of the so-called Keynesian policies is their comprehensive and coordinated character. In the post War period, the dominant economic view believed the Keynesian approach took fiscal policy as predominantly over monetary policy. However, Keynes argued that governments should take monetary and fiscal policies as complementary, not substitutes, and implement them in a coordinated manner. As Cardim de Carvalho summarized it in a very well-known paper on macroeconomic policies: "[i]t is the comprehensive nature of macroeconomic management that is characteristic of Keynes's approach, rather than any particular use of any particular policy instrument" (CARVALHO, 1997, p. 42).

According to Keynes, the main task of macroeconomic policies is to sustain aggregate demand when private expenditures fall under the amount needed to promote full employment. Due to its ability to influence aggregate demand, the government should work to mitigate the effects of the business cycle and promote a stable macroeconomic environment more favorable to private investments (CARVALHO, 2008).

Fiscal policy, in particular, plays a significant role in stabilizing aggregate demand since it affects national income directly and triggers a multiplier effect on private expenditures. That said, Keynes did not support the creation of deficits notwithstanding. His proposals for fiscal policy allowed for fiscal deficits during recessions, but also fiscal surpluses during expansions, acting as an automatic demand stabilizer.

According to Cardim de Carvalho (1997), Keynes advocated the creation of two separate fiscal budgets - one for current, ordinary government expenses, and another for discretionary public investments. The former should be balanced at all times, whereas the latter should act to stabilize aggregate demand since it would cover investment projects to be implemented or interrupted according to the phase of the business cycle. 
The ability to dissipate uncertainty and influence expectations towards the future of aggregate demand is a key aspect of fiscal policy. A well-designed fiscal policy signals to private agents that the government is willing and capable to act when needed to sustain aggregate demand. It should also induce entrepreneurs to give up on investing in more liquid assets and turn to (illiquid) fixed capital instead, thereby raising private expenditures and income. According to Cardim de Carvalho (1997, p. 44), "a successful initiative should convince private agents that aggregate incomes could be sustained, reducing their uncertainties and inducing them to put into practice their own investment plans."

Taking Keynes's perspectives on effective demand and the role of expectations into account, next section will discuss the rationale and the impact of austerity policies on output.

\section{AUSTERITY POLICIES IN THE SHORT AND LONG-RUN}

\subsection{THE ECONOMIC CONSEQUENCES OF NEGATIVE OUTPUT SHOCKS}

In one of his last published papers, Cardim de Carvalho (2018) focused on austerity policies and compared the arguments supporting austerity measures in the 1920s and the 2010s. For the discussion developed here, two elements should be stressed. First, confidence effects are always a central issue when it comes to the expansionary impacts of austerity policies. That is, fiscal consolidation could raise the confidence of consumers and investors, leading to an increase in expenditures. Second, the current debate on austerity in Europe, led by the German Federal Ministry of Finance, emphasizes the importance of internal devaluations for economic recovery. In other words, structural reforms aimed to reduce labor costs and increase productivity should be considered an integral component of the austerity package to be implemented along with fiscal consolidation. The resulting gains in competitiveness would be able to induce higher net exports, leading to economic recovery. ${ }^{1}$

Botta (2018) makes a critical analysis of the expansionary austerity theory and presents three different channels through which fiscal contractions can stimulate the

\footnotetext{
It should be noted that, by definition, this policy cannot be successful for all countries at the same time since one country's expansion of net exports means expansion of trade deficits for another country. Therefore, "successful" internal devaluations do not eliminate unemployment; it merely exports it to other countries.
} 
economy. The main rationale here is that cuts in government expenses induce an increase in other components of aggregate demand - consumption, investment, and exports.

The first channel is the so-called 'expectation channel'. In this case, a short-term decrease in government expenditures would lead households to form optimistic expectations about future cuts in taxes and, consequently, an increase in their permanent income. The result expected by theory should be an immediate increase in consumption.

The second channel to be considered is a 'financial channel', taken as the contemporary counterpart of loanable funds theory since its main impact would occur via interest rates. Here, fiscal consolidations should be able to correct public deficits and reduce public debt, thus increasing confidence in the soundness of government finance and promoting a decline in interest rates on bonds. Lower interest rates, in turn, would foster investments and economic growth.

Lastly, there is the so-called 'export-led' channel, which relates to the idea of internal devaluations mentioned above. In this case, the government should cut public wages and adopt other measures to promote a decline in real wages to gain competitiveness and induce growth via increasing exports. This type of policy is an alternative to competitive devaluations for non-monetarily sovereign countries, such as those in the Eurozone.

A considerable amount of controversy exists as to whether these channels operate, how intense their impacts are and in which circumstances they do not function. The conventional argument is that even if the positive impacts on consumption, investment, and exports do not materialize in the short-run (to the amount necessary to counterbalance the cuts in government spending), a trade-off between short-term pain and long-term gain would take place. The resulting recession in the short-run should be seen as a temporary setback needed for the economy to restore its financial health, this being a precondition for robust future growth. If that is the case, such aggregate demand shocks would result in transitory departures from trend or 'normal' output determined by aggregate supply factors, but would not bring about negative persistent effects on economic growth.

However, economies may take a long period to recover from negative output shocks, as the experiences of the 1930s and the 2010s suggest. As Cardim de Carvalho (2016) stressed, the great depression of the 1930s was crucial for Keynes's theoretical developments:

the possibility of an economy getting 'stuck' in a low level of activity for an indefinitely long period of time seemed also to be the point of Keynes's concept of unemployment equilibrium in The General Theory. (CARVALHO, 2016, p. 454) 
Cerra and Saxena (2008) provide empirical evidence on the effects of currency crises, banking crises and political crises on GDP for a sample of 190 countries from 1960 to 2001 . Their results suggest that, in most cases, output losses persist even ten years after the initial shock.

Ball (2014) estimated the long-run effects of the global financial crisis of 20082009 for a sample of 23 OECD countries. The analysis compared estimates of potential GPD for 2007 and 2014 based on data from OECD and IMF. The results suggest that most countries in the sample lost potential output after the financial crisis. Besides, Ball (2014) shows that such a loss is highly correlated with the decline of actual output from its pre-2008 trend, which implies very strong hysteresis effects during the period.

\subsection{AN INTERPRETATION BASED ON KEYNES AND CARDIM DE CARVALHO}

That a long-lasting recession might take place - i.e., that economies hit by a negative output shock may take too long (or may not be able at all) to resume their previous growth path - requires proper theoretical explanation. This explanation is usually not to be found in conventional macroeconomics textbooks, which in most cases assume that the effects of adverse output shocks are temporary and have no impacts on potential output.

In particular, regarding the effects of the 2008 financial crisis, the paramount question to ask is: why is the stagnation persistent? Or, in other words, why are the economies unable to resume their previous growth paths?

From a Keynesian perspective, persistent stagnation is not a novelty and, as mentioned before, it was one of the pillars of Keynes's idea of unemployment equilibrium. That is, Keynes and the Post Keynesians would not expect market forces to correct recession or depression automatically, leading the economy to recovery and a new cycle of prosperity.

As for the current state of developed economies, especially in the Eurozone, it is noteworthy that not only the size of the initial shock in 2008-2009 but also, and above all, the concerns with the troubling size of fiscal deficits and public debt that led to the adoption of austerity policies amidst a recessionary phase. Thus, the initial effects of a large negative shock - which can be persistent in itself, as the empirical evidence presented by Cerra and Saxena (2008) suggests - are connected to the additional adverse impacts that policies of fiscal consolidation brought about before the economies had recovered from the initial shock.

Cardim de Carvalho (2016) frames the issue in terms of depth and duration of the crisis and formulate two hypotheses to explain the occurrence of these two features: 
The first states that the shock represented by the original crash may change the parameters that regulated the operation of the economy. The second is that policies adopted to face the consequences of the crash, such as those identified as austerity policies, may actually prevent a full recovery from taking place. (CARVALHO, 2016, p. 456, emphasis added)

Admitting to these two hypotheses means that either the persistent effects of large shocks or the adoption of restrictive policies may explain a prolonged stagnation, thus defining a 'policy-led stagnation.'

Cardim de Carvalho (2016) adapts the concept of 'corridor of stability', originally proposed by Leijonhufvud (1973), to describe the range of fluctuations that the economy could absorb without promoting changes in its long-run path. Leijonhufvud (1973, p. 32) defines the 'corridor' as a range around the 'full coordination'2 path of the economic system where "the system's homeostatic mechanisms work well, and deviations counteracting tendencies increase in strength." ${ }^{3}$ According to Leijonhufvud, Keynesian unemployment is associated with effective demand failures derived from shocks that move the system far enough from its full-coordination path, so that the forces tending to bring the economy back to the original position become weak or sluggish. Thus, one could expect the system to recover from shocks and return to the previous path if the size of the fluctuation does not go beyond a given level. In the case of depression, the decline in economic activity would be deep enough as to prevent the economy to return to the original growth trend.

However, Cardim de Carvalho (2016) does not fully subscribe to Leijonhufvud's perspective on the corridor of stability, since it is associated with market-clearing and full employment equilibrium. Instead, Cardim de Carvalho (2016) abandons the idea of a "full coordination path" and only retains the notion that the economic system may react differently to small and large shocks, the latter being the ones that disorganize the system and change its dynamics.

Cardim de Carvalho (2016) relates the corridor of stability to the notion of normality and defines it as:

\footnotetext{
2 A full coordination path is defined as a stable equilibrium path of the economic system, characterized by market-clearing (thus, full employment). After small shocks, the system is assumed to have an automatic tendency to move towards the coordinated path.

3 Homeostasis is the tendency of a system to maintain internal stability, owing to the coordinated response of its parts to any situation or stimulus that would disturb its normal condition or function.
} 
that range of values of the relevant variables that is recognized as normal by economic units, such that any variation of those values within the expected range can be absorbed without changing the parameters of the system. (CARVALHO, 2016, p. 457)

By associating the concept of corridor of stability to that of normality, Cardim de Carvalho comes to a broader use for the former. In this case, the definition of an equilibrium path is less restrictive since it does not depend on full employment or market-clearing prices. It is associated with a situation considered to be 'normal' by economic agents, even if it comprises unemployment or production below full capacity.

It is worth noting that Cardim de Carvalho (1990) explored the idea of normality in an earlier paper, where he related it the notion of "long-period" in Keynes, due of his Marshallian background. Marshall defined normality as a situation in which 'conditions were stable enough to allow agents to make their normal choices in the face of these conditions' (CARVALHO, 1990, p. 281). Moreover, Cardim de Carvalho (1990) stressed that the concept of normality, in Keynes, is closely related to the notion of convention. Therefore, economic agents' past experiences, reactions, and expectations should be taken into account when defining a new normal.

By working with the concept of corridor of stability, Cardim de Carvalho (2016) argues that the economic system reacts to small and to large shocks differently. That is, in some cases, it is capable of absorbing shocks and keeping its normal path unchanged; in others, shocks cannot be absorbed, disturbing the parameters and dynamics of the system, and eventually changing its trajectory. Thus, the corridor of stability defines a threshold for the economic system to absorb shocks and keep its normal path.

If the fall goes deep enough (...), material and expectational variables may change in such a way that after a while a new normality will be recognized, around which another corridor of stability will be created. Under circumstances like this, an unemployment equilibrium, with the features Keynes described it in The General Theory, can prevail as the new normal. (CARVALHO, 2016, p. 458, emphasis in original)

In this paper, we use the concept of the corridor of stability but argue that changes in "normal" values may not be caused necessarily by large shocks. Under some circumstances, it can be argued that small shocks followed by contractionary policies may give rise to a new normal path for the economy.

Botta (2018) develops a model in which agents form expectations "in a myopic fashion" under deep uncertainty. As Keynes had already argued in the General Theory, 
it is rational for agents to take the present as a guide for the future when under deep uncertainty. In Botta's (2018) model, firms revise their expected level of capacity utilization (or output) downward when current capacity utilization (or output) is lower than expected.

In this case, after an initial decline in output, caused by an adverse demand or supply shock, agents may revise expectations downwards. If the government adopts fiscal austerity policies, with further negative effects on output, the economy may experience successive revisions of short-term expectations that feed back into current production decisions, and so on, in a cumulative way. Therefore,

Path dependency and cumulativeness make the short-run effects of fiscal consolidation elements of paramount importance to (...) obtaining any medium-tolong-run benefit. Should these effects be even slightly contractionary, short-run costs can breed an endless spiral of recession and ballooning debt in the long run. (BOTTA, 2018, n.p.)

To phrase the argument in terms of the corridor of stability, a prolonged stagnation and the definition of a new 'normal' growth path may be explained not only by large negative shocks that take the economy out of the corridor of stability, as Cardim de Carvalho (2016) put it. A new growth path may also be a consequence of cumulative adjustments initiated in a small adverse shock and fed by austerity policies that defer recovery. In this case, leaving the corridor of stability may be a gradual move through successive rounds of adjustment. Thus, the longer the recession, the higher is the probability of the economy not returning to its original path - as if the system had a memory of its past that fades over time.

In other words, if one assumes that the economic system has a memory of its prior path, long deviations from it may give rise to a new trend that will be acknowledged as the new normal and establish a new corridor of stability. It is worth noting that the concept of corridor of stability remains valid, nonetheless; but in this case not only the size of shocks but also their duration matters, so a temporal dimension must be added to the concept.

The definition of a new normal path may also be related to hysteresis, which is the inability of a system to return to its previous state after an exogenous shock. Or, in other words, hysteresis effects can be defined as those that persist even after the initial causes giving rise to them are removed (CROSS, 1993).

According to the perspective developed here, shocks that could eventually be absorbed by the economy, without changing the output trend, become permanent as the duration of the slump gets long enough due to austerity policies. Thus, a 
new normal path characterized by higher unemployment and lower growth rates takes place. ${ }^{4}$

\subsection{KEYNES SHIFTING EQUILIBRIUM MODEL AND THE ROLE OF EXPECTATIONS}

It is interesting to note that for Cardim de Carvalho (2016) 'changing parameters' of the economy plays a prominent role when defining the corridor of stability and the possibility of trend stationarity in output. However, he does not explain further which parameters may change and how such changes would affect the system.

This paper contributes to the debate by offering a specific interpretation of Carvalho's proposition based on Keynes' shifting equilibrium model, as presented by Kregel (1976). Keynes is known to have built his works on different assumptions regarding expectations and their role in the short and long-run. Accounted as his most complete model, the so-called model of shifting equilibrium provides an accurate analysis of the role of expectations in decision-making under uncertainty. In this model, short-term expectations may change due to unforeseen results, and such changes, in turn, affect long-term expectations (KREGEL, 1976).

Thus, long-period expectations may shift in reaction to shocks in the system, and this, in turn, affects the 'fundamental psychological variables' that determine aggregate demand, namely, the propensity to consume, the liquidity preference, and the marginal efficiency of capital. ${ }^{5}$

In other words, the 'fundamental psychological variables' or, to put it in Carvalho's (2016) terms, the 'parameters that regulate the operation of the economy' may be endogenous to economic activity and therefore respond to short-run demand shocks via changes in expectations. In particular, for this paper, it is worth pointing out that such parameters may respond to fiscal contractions through different channels, which, in turn, may push the economy to different long-run paths.

First, short-run contractions may affect the propensity to consume since the fear of losing one's job amid a recession may induce a precautionary behavior of households

4 Dutt and Ros (2007) present formal models in which aggregate demand shocks affect output growth in the long-run. One of their main conclusions goes in the same direction as the arguments presented here: "aggregate demand contractions should be small, and should be reversed as soon as possible, in order to mitigate their adverse long-run consequences” (DUTT and ROS, 2007, p. 98).

5 For formalizations of Keynes's shifting equilibrium model, see Dutt (1997) and Setterfield (1999). In both cases, the models present path-dependence and multiple equilibria, in line with the possibility that the economy may not return to a predetermined trend after shocks. 
and lead to higher savings. This, in turn, implies lower multiplier effects and even stronger negative impacts on aggregate demand.

Secondly, fiscal consolidations may affect liquidity preference, given that a declining economic activity usually leads to an increase in debt defaults and therefore to a more conservative approach to lending by banks. Either a shortage of credit or an increase in interest rates on loans would follow, which would bring about negative effects for firms, on the one hand, due to higher financial costs on working capital and on the financing of investment in capital goods, and for households, on the other, due to higher cost of financing consumption of durable goods. In both cases, a negative impact on aggregate demand is to come, leading to an even deeper recession, in opposition to the conventional expansionary austerity proposition.

Lastly, government budget cuts may affect the marginal efficiency of capital, i.e. the expected profitability of investments. In this case, a lower demand in the present may is likely to create expectations of lower demand in the future, and if so the corresponding decrease in expected capacity utilization is to induce a decline in the expected profit rate and lead to lower investment expenditures. Once more, the resulting effect would be a long-run equilibrium with lower potential GDP. ${ }^{6}$

The arguments developed above relate to Carvalho's outline of a theory of depressions, according to which "the shock represented by the original crash may change the parameters that regulated the operation of the economy" (CARVALHO, 2016, p. 456). Here, the connection between Carvalho's two hypotheses to explain economic stagnation is that a recession, which is prolonged by austerity policies, may be the cause of changing parameters due to its effects on expectations. As argued before, it is not only the depth but also the length of the recession that matters for the system's ability to absorb the initial shock and return to a predetermined growth trend. To frame this discussion in terms of Carvalho's corridor of stability, the argument presented here is that by extending the length of a recession austerity policies may change (the normal values of) the propensity to consume, the liquidity preference, and the marginal efficiency of capital, and, thus, bring about a new definition of ('longperiod') normality.

6 Dutt (2013) presents a model where an increase in government expenses leads to higher growth rates in the long-run. The model assumes that labor productivity responds to the employment rate positively because firms tend to invest more in labor-saving technologies when the labor market becomes tighter. Also, labor productivity depends on government investment in infrastructure and technology. In this case, the model presents a continuum of equilibria, and the actual long-run equilibrium position of the economy is path-dependent. For instance, if the economy faces recession followed by austerity policies that prevent recovery, lower rates of accumulation and employment growth harm the rate of growth of labor productivity, and a lower rate of per-capita income growth in the long-run will follow. 
In sum,

the revision of long-term expectations given current outcomes implies (...) that the underlying determinants of aggregate demand (or the fundamental psychological variables: the propensity to consume, liquidity preference, and the marginal efficiency of capital) are endogenous to the path of the economy. In this case, the long-run equilibrium will itself respond to short-run outcomes, and one should not expect the economy to converge to any predetermined path. (LIBANIO, 2006, p. 135-136)

\section{CONCLUSIONS}

This paper discussed from a Post Keynesian perspective the role of austerity policies in the long-run path of the economy. The analysis starts by acknowledging that fiscal policy is a relevant source of demand stabilization. Considering how the principle of effective demand operates in the short and long-run, the paper argues that negative demand shocks may bring about long-lasting effects.

The impact of austerity policies on output is explored in this paper with the use of two theoretical tools. The first one is the concept of the corridor of stability, adapted by Cardim de Carvalho (2016) to outline a theory of depressions. The second one is Keynes's model of shifting equilibrium, as presented by Kregel (1976).

We argue that an initial decline in output caused by an adverse demand or supply shock and followed by contractionary fiscal policies that prolong the recession may change the 'fundamental psychological variables' - namely, the propensity to consume, the liquidity preference, and the marginal efficiency of capital - and define a new growth trend for the economy.

Here, not only the depth but also the length of the recession matters for system's ability to absorb the initial shock and return to a predetermined growth trend. If one assumes that the economic system has a memory of its past that fades over time, long deviations from its previous path may give rise to a new trend that will be acknowledged as the new normal, around which a new corridor of stability will be defined.

We conclude by quoting Cardim de Carvalho:

Unemployment equilibrium states are, therefore, explained by both objective and subjective factors. On the one hand, there is the burden of actual losses and debt overhang and irreversible events, such as bankruptcies. On the other, there is a perception by economic agents that such facts shape the current and prospective operation of the economy. (CARVALHO, 2016, p. 465) 


\section{REFERENCES}

ALESINA, A. et al. The effects of fiscal consolidations: theory and evidence. NBER Working Paper, n. 23385, November 2017.

BALL, L. Long-term damage from the great recession in OECD countries. NBER Working Paper, n. 20185, May 2014.

BLYTH, M. The austerity delusion: why a bad idea won over the West. Foreign Affairs, v. 92, n. 3 , p. 41-56, 2013.

BOTTA, A. The short- and long-run inconsistency of the expansionary austerity theory: a post Keynesian / evolutionist critique. Journal of Evolutionary Economics, v. 30, p. 143-147, 2018. https://doi.org/10.1007/s00191-018-0567-3.

BOTTA, A.; TORI, D. The theoretical and empirical fragilities of the expansionary austerity theory. Journal of Post Keynesian Economics, v. 41, n. 3, p. 364-398, 2018.

CARVALHO, F. J. C. Keynes and the Long Period. Cambridge Journal of Economics, v. 14, n. 3, p. 277-290, 1990.

CARVALHO, F. J. C. Economic Policies for Monetary Economies. Brazilian Journal of Political Economy, v. 17, n.4, p.31-51, 1997.

CARVALHO, F. J. C. Equilíbrio fiscal e política econômica keynesiana. Revista Análise Econômica, ano 26, n. 50, p. 7-25, 2008.

CARVALHO, F. J. C. In this 'it'? An outline of a theory of depressions. Brazilian Journal of Political Economy, v. 36, n. 3, p. 451-469, 2016.

CARVALHO, F. J. C. Arguments for austerity, old and new: the British Treasury in the 1920s and the Bundesfinanzministerium in the 2010s. European Journal of Economics and Economic Policy: Intervention, v. 15, n. 3, p. 262-288, 2018.

CERRA, V.; SAXENA, S. Growth dynamics: the myth of economic recovery. American Economic Review, v. 98, n. 1, p. 439-457, 2008.

CROSS, R. On the foundations of hysteresis in economic systems. Economics and Philosophy, v. 9, n. 1, p. 53-74, 1993.

DUTT, A. Equilibrium, path-dependence and hysteresis in Post-Keynesian models. In: ARESTIS, P.; PALMA, G.; SAWYER, M. (Eds.) Markets, unemployment and economic policy. Essays in honor of Geoff Harcourt. New York: Routledge, 1997, v. 2.

DUTT, A. Government spending, aggregate demand and economic growth. Review of Keynesian Economics, v. 1, n. 1, p. 105-119, 2013.

DUTT, A.; ROS, J. Aggregate demand shocks and economic growth. Structural Change and Economic Dynamics, v. 18, n. 1, p. 75-99, 2007.

GIAVAZZI, F.; PAGANO, M. Can severe fiscal contractions be expansionary? Tales of two small European countries. NBER Working Paper, n. 3373, May 1990.

KEYNES, J. M. The general theory of employment, interest and money. London: Macmillan, 1936.

KEYNES, J. M. The collected writings of John Maynard Keynes. London: Macmillan, 1973, v. 13. 
KING, L. et al. Making the same mistake again - or is this time different? Cambridge Journal of Economics, v. 36, n. 1, p. 1-15, 2012.

KREGEL, J. Economic Methodology in the face of uncertainty: the modeling methods of Keynes and the Post-Keynesians. Economic Journal, v. 86, p. 209-225, 1976.

LEIJONHUFVUD, A. Effective demand failures. The Swedish Journal of Economics, v. 75, n. 1, p. 27-48, 1973.

LIBANIO, G. Unit roots in macroeconomic time series and stabilization policies: a Post Keynesian interpretation. In: WRAY, W.; FORSTATER, M. (Eds.) Money, financial instability and stabilization policy. Cheltenham: Edward Elgar, 2006.

PEROTTI, R. The "Austerity Myth": gain without pain? NBER Working Paper, n. 17571, November 2011.

SETTERFIELD, M. Expectations, path dependence, and effective demand: a macroeconomic model along Keynesian Lines. Journal of Post Keynesian Economics, v. 21, n. 3, p. 479-501, 1999.

SHAPIRO, N. Keynes, Steindl, and the Critique of Austerity Economics. Monthly Review, v. 64, n. 3, 2012.

STEINDL, J. J. M. Keynes: society and the Economist. In: VICARELLI, F. (ed.) Keynes's relevance today. London: Macmillan, 1985. 